\title{
"If You Are Not the King You Will Be Eventually ... ": Eastern and Western Prophecies Concerning the Rise of Emperors
}

\section{Idan Breier}

The Israel and Golda Koschitzky Department of Jewish History and Contemporary Jewry, Bar-Ilan University, Ramat-Gan 5290002, Israel; Idan.Breier@biu.ac.il

Received: 7 November 2019; Accepted: 10 December 2019; Published: 19 December 2019

\begin{abstract}
This article compares three literary-historical texts-two from the Jewish world and one from Mongolia - that record prophecies given to military commanders asserting that they will become the rulers of great empires and civilizations. In his The Jewish War, Josephus tells us that he prophesied that Vespasian would become emperor, an act that appears to have saved his life. A rabbinic tradition, related in several versions, similarly recounts that R. Johanan b. Zakkai prophesied that Vespasian would rise to power-he, too, thus being granted his freedom and the opportunity to rebuild his life and community in Yavneh. I compare Josephus and R. Johanan's prophecies in the light of The Secret History of the Mongols. A chronicle describing the life of Temüjin, the founder of the Mongol Empire who gained fame as Genghis Khan (1162-1227), this tells how Temüjin, the young commander, was predicted to unite all the Mongol tribes and rule over a vast empire. The article analyzes the three prophecies, which occur in diverse genres, in the light of their historical background, hereby demonstrating the way in which written sources can serve anthropological phenomenological research and shed new light on ancient Jewish texts.
\end{abstract}

Keywords: prophecy; comparative phenomenology; Josephus; Rabban Johanan ben Zakkai; Vespasian; Genghis Khan; great civilizations

\section{A Methodiacl Introduction}

This article examines three prophecies of the rise to power of military commanders-two from the end of the Second Temple period and one from medieval Mongol history. Employing a comparative historical approach, it seeks to reveal new patterns, affinities, and disparities between the three cases, thus shedding new light on some of the great ancient civilizations (Kedar 2009; Mandelbaum 1980). Tracing the commonalities between them, it also serves as an exercise in comparative phenomenology (Knibbe and Versteeg 2008; Desjarlais and Throop 2011). ${ }^{1}$ In this sense, it may serve to bridge two fields of knowledge - on occasion even between cultures that do not appear to emerge from a common source (Schnegg 2014, pp. 57-58; Mace and Pagel 1994, pp. 545-64). Specifically, I present and analyze the circumstances in which prophecies were spoken, the personal situation/state of the individual who delivered it, the reward he gained for doing so, the way in which he came to make it, and whether it reinforced earlier signs or portents.

Over 1000 years separate the two civilizations under investigation, and the discussion is also intercultural and interperiod-a method increasingly prominent in contemporary historical study of the ancient world (Murnane 2003; Valbelle 2003; Breier 2011; Charvát 2013). Mongolian scholars,

1 For the potential comparative studies carry, see recently (Hajdu and Kálmán 2019, p. 391). 
indeed, have recently drawn attention to the affinities between biblical history, the days of Alexander the Great, and the stories of Genghis Khan (Bartlett 2009, p. 22; Man 2014, p. 29; Weatherford 2016, p. 246). These claims not having been conclusively proven; however, I hope herein to provide a concrete phenomenological example relating to the study of Second Temple Judaism and the end of this historical period.

The cross-cultural comparative method forms an important element of Durkheim's (1858-1917) sociology. In his view, studying several cultures across various locations and periods serves as a better way to understand society and its institutions (Durkheim 1982, pp. 157-58). Prominent 20th-century historians also espoused the same view. Edward Carr (1892-1982) and Marc Bloch (1886-1944), for example, both argued that historical comparisons can be adduced between diverse places and times, thereby furthering insight into historical events (Carr 1964, pp. 107-8; Bloch 1953, pp. 43-44). Bloch even argued that we can compare European feudalism with its Japanese counterpart (Bloch 1961, pp. 441-47). Acting professionally and avoiding the trap of superficial comparison, historians can thereby add another working method to their toolbox (Singer 2004, p. 13; Baumgarten 2007, pp. 44-45).

In the spirit of this approach, some contemporary comparative scholars have followed up Bloch's proposal and begun to study Japanese and European feudalism (Perez 1998, pp. 28, 36; Shillony 2001, pp. 180,186). Others have drawn attention to the affinities between present-day European and American political entities and classical Greece, imperial Rome, and early China (Kokaz 2001, pp. 91-102; Tod 2003, pp. 59-99; Cox et al. 2001, p. 6; Zhang 2001, p. 63 respectively). Comparisons have also been drawn between guerilla fighters/terrorists in Afghanistan today and the political history of the ancient Near East (Morris 2010, pp. 413-38). More relevant to our present purposes, Raphals has also studied divination and prediction in early China and ancient Greece (Raphals 2013).

Cross-cultural comparison may rest on the premise that human nature changes very little (if at all) throughout history. This view can be discerned as early as Thucydides, also being embraced in the 19th century by European and Chinese scholars (Thucydides 2013, Book 3, par. 82; cf. Asheri 2004, p. 71; Fuks 2005, p. 142; Puchala 2003, p. 37; Hsü 2000, pp. 360-61, Sowell 2002).

This brief survey demonstrates that the use of the comparative method and its examination of similarities and disparities across places and times can raise new questions, thus shedding light on the events discussed. I submit that comparison, in particular between widely separated phenomena-such as East and West, as addressed herein — can affirm the plausibility of an act by demonstrating that it occurs in other cultures as well. Deeds on occasion not being particularly well known in one culture and thus rather dubious, they can be validated by their presence in another, comparison of the two evincing a pattern of behavior in similar situations.

\section{Prophecies to Military Commenders in the Bible and Ancient Sources}

Before turning to our test cases, let us first examine the phenomenon of prophesying to military commanders as reflected in the Hebrew Bible and Graeco-Hellenistic-Roman literature.

The biblical historiographical writings contain numerous prophecies predicting the rise of (future) rulers. When Abigail attempted to prevent David from murdering her husband, Nabal the Carmelite, and his men as David was seeking to escape Saul's clutches, she laid a sophisticated argument before him explaining why he should let them live (1 Sam 25:2-31) (Wright 2014, p. 6). Herein, she reinforces the words of Samuel the prophet, who anointed David king instead of Saul. After Nabal's death, she joins David's camp and goes so far as to marry him (1 Sam 25:39-42) (Hertzberg 1964, p. 204; Klein 1983, p. 215; Bar-Efrat 1996, p. 322; Garsiel 2018, p. 185). Although some scholars contend that the narrative exhibits traces of tendentious editing, the prophecy given to David that his house would sit upon the throne by a figure from the rival camp is designed to mitigate the behavior of the faction leader and obligate him to conduct himself with statesman-like responsibility (McCarter 1980, pp. 401-2; Halbertal and Holms 2017, pp. 60-61; cf. McKanzie 2000, pp. 96-101; Baden 2013, pp. 96-97). 
In Samuel and Kings, and the parallel passages in Chronicles, one of the principal roles of the early prophets was to enthrone and depose kings, reflecting God's approval or disapprobation of the person appointed to the office (Uffenheimer 1984, pp. 151-54; Eilat 1998, pp. 81-114; Lorberbaum 2008, pp. 37-38; Eph'al-Jaruzelska 2009, p. 65). Elisha's prediction to Haza'el, commander-in-chief to Ben-Hadad II, king of Aram, is a special case, however: "The LORD hath shown me that thou shalt be king over Aram" (2 Kgs 8:13) (Uffenheimer 1984, p. 264; Miller and Hayes 2006, p. 328). ${ }^{2}$ Killing the king to fulfill the prophecy, he usurps the throne- a fact documented in Assyrian sources as well as the biblical text: "Hadad-ezer [Adad-idri] passed away (and) Haza'el, son of a nobody, took the throne" (A 0.102.40, i 25-27; RIMA 3, 118 [Grayson 2002]). After Elisha's lifetime, however, during which Jehu instigated a bloody rebellion, the prophets ceased becoming directly involved in the appointment and deposal of monarchs, focusing primarily on rebuking those on the throne privately and publicly (Gelander 2008, p. 55). While they continued intervening in political affairs, perhaps even on a more extensive scale than before, they no longer participated in the inauguration/removal of royal figures or calling for revolutions. Rather than seeking to replace rulers, they began appealing to the king and people to mend their ways in order to avert impending disasters (Fenton 2001, pp. 87-88).

Before turning to later examples, we may note that prophecy was a well-known phenomenon across the ancient Near East, falling into the following two principal categories:

(a) Intuitive prophecy. Prominent in the biblical texts, this is also documented-albeit in simpler form-in ancient Near Eastern literature (Malamat 1995, pp. 50-73; Nissinen 2003, pp. 13-78; Barsted 2006, pp. 21-52; Anbar 2007, pp. 33-89). Primarily associated with dreams, this form also occurred in ancient Greece (Fidler 2005; Nissinen 2017);

(b) Indicative prophecy, grounded primarily in signs and portents sent by the gods and interpreted by experts (Van De Mieroop 2016, p. 89).

The sources evince the existence of numerous modes of prophecy-reading animal livers, bird flight, etc. These traditions were written down and passed from generation to generation and region to region-Babylonian extispicy manuals making their way to Hatti, for example, and thence to Greece and Rome (Kessler-Guinan 2002, pp. 9, 10, 18-20; Frantz-Szabó 1995, p. 4; Rosenberger 1998, pp. 199-203). ${ }^{3}$

Signs and wonders linked to the throne are well known in both Greek and Roman historiography. Early on, Herodotus records a portent dreamt by Astyages of Media, in which he was told that he would have a grandson, Cyrus, who would usurp him. ${ }^{4}$

In contrast to Herodotus, Thucydides sought to downplay the involvement of the superpowers in world history (Fuks 2005, p. 142). However, he also recorded for his readers an omen interpreted by the Athenians as a sign of a change in regime and the fall of democracy in the city (Thucydides 2013, Book 6, par. 27; cf. Zagorin 2005, pp. 111-12). The Graeco-Roman historian Plutarch reports portents preceding the birth of Alexander the Great that augured his rise to greatness (Plutarch, Alex. 2; cf. Hägg 2012, p. 121). We may also observe how, in his Aenead, Virgil details numerous prophecies or signs portending a rise to power $(3.90-98,154-171,7.58-70,95-101){ }^{5}$ In Roman historiography, Suetonius served as a model for other biographers after him, primarily due to his custom of looking at their lives from the moment of their birth, also presenting their family background prior to their conception (Mellor 1999, p. 158). His accounts thus contain numerous signs given to the imperial rulers who lived prior to Vespasian - who I shall discuss below. Omens and prophecies are thus adduced in relation to Julius Caesar, Augustus, Tiberius, and Gelba (Suetonius, Jul. 1.7; Aug. 94-95; Tib. 14; Galba 1.18;

\footnotetext{
Biblical quotations herein follow the NKJV.

Ancient Near Eastern influence upon Greek culture is also evinced in the field of proverbial sayings: see (Adrados 1999, vol 1, p. 305; Karhonen 2019, p. 213).

4 Cf. also the account of the sign embodied in the horse's glee in the story of Darius' election (Herodotus 3.85).

5 For the prophecies in this work, see (Santangelo 2013, pp. 225-34).
} 
Vit. 3; cf. Lattimore 1934, pp. 443-49). Portents and prophecies also appear in a similar context in Cassius Dio (who is most interested in heavily omens) and Tacitus-the latter further noting that the Romans attach great significance to signs (Tacitus, Hist. 1.22, 2.1; Cass. Dio 39.13, 47.1-2, 53.20; 55.1, $61.2,64.7-8,16,66.1)^{6}$

In the majority of cases, the various omens and dreams related to the right of a man without any strong genealogical support-i.e., no legitimate right as heir-to take the throne or seek to introduce change or reform. Julius Caesar turned the republic into a monarchy, for example (Weber 2000, pp. 147-48, 159-60, 180-89; Engels 2007, pp. 128-29, 185-86). For the sake of comparison, we may also note the historical background lying behind the dreams recorded by ancient Near Eastern rulers (Fidler 2005, pp. 341-60).

\section{First Case Study: Josephus' Prophecy to Vespasian}

The two prophecies we shall analyze here from the end of the Second Temple period were delivered to Vespasian —one by Josephus and one by Rabban Johanan b. Zakkai. The first is recorded in the Jewish Wars, while Josephus did not include it in his Life. Although in the Wars he presents himself as a key figure in the revolt against Rome in the Galilee, in his later writings, he stresses the fact that he served as a moderating factor in the conflict (B.J. 3.340; cf. Vita 71-93, 208-211). Whatever the case may be in this regard, he appears to have played some role in the events in the north (Schwartz 1990, p. 209). As a sophisticated historiographer, he wrote for the Romans and his fellow countrymen in Judah and the diaspora simultaneously, adapting his style to fit the circumstances and his audience (Pucci 1982; Curran 2011, p. 80; Schwartz 2011, p. 342; Lü 2015, pp. 90-91). Exhibiting an increasing tendency to present the Jews in a favorable light, he attributes most of the blame for the failure of the revolt in the Wars to a small, fanatical zealot group (läistai-a rather inclusive term) and the sicarii, who were intent on a full-scale rebellion against Rome at any cost. ${ }^{7} \mathrm{He}$ even appears to have sought to draw an analogy between the Great Revolt and the outbreak of the civil war in Rome (B.J. 1.1-2, 9-10, 6.41-409; Mason 2005a, pp. 254-55, 263-65). In general, Josephus seeks to convey the fact that Jews can live in a dignified fashion under Roman rule (Lü 2015, pp. 90-96). According to Josephus in his introduction to the Wars, following the fall of Yodfat he hid in a cave with a group of fighters, urging them not to commit suicide. When they disregarded his advice, he himself declined to follow their example and take his own life rather than surrender (B.J. 3.355-392). Although some scholars view this as a striking instance of his particular interests, it undoubtedly being difficult to ascertain the "true facts" behind the story, others hold it to contain a kernel of truth. ${ }^{8}$ Scholarly attention in this regard focuses primarily on the incident we are discussing here, in which, on coming out of the cave as the lone survivor, he presents himself before Vespasian and prophesies his future to him:

"Vespasian, you may think that in Josephus you have simply won yourself a prisoner of war: but I am come to tell you of your greater destiny. If I were not God's chosen emissary, I would have followed the Jewish tradition-I know it well, and how a defeated general should meet his death. Are you sending me to Nero? Why to him? Do you think Nero and his successors will last long before your hour is come? You, Vespasian, will be Caesar and emperor, both you and your son here with us. So chain me tighter now and keep me for yourself, as you, Caesar, are master not only of me but of all land and sea and the whole

6 For the numerous omens Dio reports in his account of the civil wars, see (Westall 2016, pp. 51-75).

7 B.J. 2.445, 449, 525, 529, 538, 540, 5.28, 53, 365, 333f; A.J. 20.116, 172. See (Nikiprowetzky 1989, p. 231; Rajak 2005, p. 95; Schwartz 2007, p. 147; Hengel 1989, p. 11; Mader 2000, pp. 12-14; Parente 2005, pp. 67-68; Howell-Chapman 2005, p. 300; Regev 2011; Brighton 2009, pp. 64, 137, 142).

8 For the former perspective, see (Klawans 2012). For the latter stance, see (Newell 1989, pp. 288-89). For the problematics of the narrative, see (den Hollander 2011, p. 94). 
human race. Punish me, please, with yet harsher confinement if I am taking the name of God in vain." (B.J. 3.400-402 [Hammond] ${ }^{9}$

Some scholars believe Josephus spoke to Vespasian on leaving his hiding place, in July 67 AD, while Nero was still on the throne in Rome. Others contend that he spent some time as a captive awaiting transport to Rome, only giving the prophecy after Nero's suicide (in 68) in 69-known as the "Year of the four Emperors" (B.J. 3.290-291) (Schalit 1975; cf. Levick 1999, p. 67).

Whatever the case may be in this regard, Roman policy in the region being primarily dictated by pragmatic considerations, the army commanders might have thought Josephus to be a useful tool for communicating with the Jewish populace: fluent in Aramaic and Hebrew, he might have been able to assist them in their psychological warfare against the rebels (Rosenfeld 1993b; Hadas-Lebel 1993, pp. 152-55). He certainly possessed typographical knowledge and information regarding the rebel forces that could serve the Romans (Levick 1999, p. 32). In this respect, the incident recalls Rabshakeh's Hebrew speech outside the walls of Jerusalem during Sennacherib's 701 campaign (2 Kgs 18:19-19:14; Isa 36:2-37:14), the commander possibly being of Israelite or Aramean origin (Levin 2011, 2015).

Although Josephus notes the decent way in which the priests who had previously delivered themselves into Roman hands had been treated, he generally seeks to present the conquerors in a far less favorable light (see B.J. 3.111-116; Alon 1977, pp. 269-313). Roman sources tell us of similar cases of the release and promotion of prisoners, especially prominent figures, painting army personnel as merciful captors (den Hollander 2011, pp. 85-86, 140, 168-69). The majority of revolts against Roman rule occurring on the outskirts of the empire, captives could provide commanders with valuable military, geographical, and topographical information (den Hollander 2011, pp. 158-91; Goodman 2001, p. 164). In a later period, Ibn Khaldūn, for example, tells us how he escaped from Damascus during the Mongol siege in AD 1401 and was met by the Mongol commander Tamerlane, who requested that he write a description "of the whole country of the Maghreb—its distant as well as its near-by parts, its mountains and its rivers, its villages and its cities-in such a manner that I might seem actually to see it" (Fischel 1952, p. 35).

Although Josephus does not appear to have expressly identified himself as a prophet, his self-presentation closely resembles the contemporary prophetic pattern (B.J. 2.341, 351-352, 354, 362, 400, 625-626; Jonquière 2011, p. 219; Grabbe 2003, p. 245). This was characterized by prediction and pronouncement of God's will rather than the broader biblical phenomenon, Judaism during this period being not only an interpretive religion but also recognizing present-day divine revelation in one form or another (Gray 1993, pp. 15-18, 28-41; Feldman 2003, pp. 227-30; Grabbe 2003, p. 244; Goodman 2007, pp. 350-51). ${ }^{10}$ As Martin Goodman observes, Josephus seems to "have assumed that prophets of his own day did not quite reach the standard of those whose inspired sayings were preserved in the Bible. Nonetheless, he was certain that God sent messages to privileged men, since he believed himself to be one such" (Goodman 2007, p. 351).

Possibly, Josephus came to speak of himself in prophetic terms over time, regarding himself a modern-day Jeremiah, suffering like him when confronted with false prophets in seeking to prevent the Temple from destruction a second time (Goodman 1987, p. 6; Gray 1993, p. 72; Feldman 1998, p. 59; 2003, pp. 212-13). ${ }^{11}$ Some scholars posit that the prophecy was in fact responsible for preserving his life-although he appears never to have enjoyed the prestigious status he claimed to have attained in Rome (Schwartz 1990, p. 5; Gray 1993, pp. 36, 79; Seward 2009, p. 101; Cotton and Eck 2005, p. 52; Curran 2011, p. 67).

9 (Goodman 2017, p. 190). See (Jonquière 2011, p. 217; den Hollander 2011, p. 143).

10 For Philo's conviction that the spirit of prophecy rested upon him, see (Levison 2003, pp. 202-9). For Jesus as prophet, see, for example, (Dunn 1981). For prophecy in the Qumran sect, see, for example, (Jassen 2008).

11 For Jeremiah as a prophet of deliverance, see (Tiemeyer 2009, p. 262). 
Although Josephus endeavors in his writings to portray himself as concerned for his people and nation, some scholars argue that his primary interest was in his own survival (Price 2009, p. 22; Bilde 1988, p. 76). Although he quite naturally sought to present his benefactors, Vespasian and Titus-both of whom were concerned to find ways to legitimize their status in the absence of good birth and lineage - in a favorable light, he also portrayed the Roman Empire as legitimate in God's sight, the latter raising and bringing down rulers according to His will (B.J. 5.367; A.J. 11.3, 334; Spilsbury 2005, p. 224; Overman 2002, pp. 215-16; Mason 2005b, pp. 97-100; McLaren 2005; cf. Southern 1998, p. 150). At the same time, however, he exhibits no ideological or emotional identification with it, in particular the idea of the Pax Romana (Stern 1991, pp. 381, 385-86, 394, 398, 402, 406, 408; Price 2009, pp. 56-57). From a cultural perspective, during the imperial period the latter bridged various societies-a phenomenon that began, albeit in limited fashion, as early as the Republic (Goldsworthy 1992, pp. 87-99; Goodman 2001, pp. 142-48; Temin 2013, pp. 22-24, 201-2, 218). ${ }^{12}$ In light of our examination of the East, we may note that similar frameworks emerged there too-such as the Pax Mongolica in the 14th century and the Pax Sinica during the Chi'ing Dynasty through the 17th to the 19th centuries (Weatherford 2004, p. 220; Hsü 2000, p. 440).

\section{Second Case Study: Rabban Johanan ben Zakkai's Prophecy to Vespasian}

The second prophecy given to Vespasian was that delivered by Rabban Johanan ben Zakkai (Lerner 2010, p. 181). The story-one of the longest biographical sections in rabbinic literature-is recorded in five places in four versions (Abot R. Nat. A 4; Abot R. Nat. B 6; Lam. Rab. 1.5.31; b. Git. 56a-b; Prov. Rab [Buber] 15 [identical to Abot R. Nat. B]). ${ }^{13}$ While most scholars regard it as a myth constructed around a kernel of historical truth rather than an historical fact (Hasan-Rokem 2000, p. 184), some doubt that it contains any verisimilitude at all (Baer 1971, pp. 176, 178, 185; Schwartz 2014, p. 85). While the rabbinic Sages do not appear to have been familiar with Josephus' writings in any form, it is reasonable to assume that they were aware of the tradition of his prophecy to Vespasian (Noam 2012, pp. 367-95). If so, this knowledge may have prompted R. Johanan ben Zakkai to take action-possibly also influencing the way in which, over the years, the midrashic story underwent various evolutions and incarnations (Ben-Shahar 2017, pp. 641, 660-64). ${ }^{14}$ It nonetheless became entrenched in Jewish memory, serving as a powerful legend anchoring and giving meaning to life after the destruction of the Temple, embodying the idea that a leader can achieve a measure of liberation. ${ }^{15}$

The latest version, preserved in b. Gittin, which has undergone extensive and tendentious editing, has been studied the most widely, followed by the earliest—Lamentations Rabbah, compiled around 200 years after the ostensible event-which, if historical, happened no later than the winter of 69/70 CE (Yisraeli-Taran 1997, p. 71; Schremer 2005, pp. 228-33; Marx 2013, p. 57; Rappaport 2006, p. 104 n. 26). ${ }^{16}$ According to the earliest version, the zealots' burning of the storehouses led Rabban Johanan to the realization that the revolt could not succeed. He thus sought a way out of the besieged city by pretending to be dead, his disciples arguing that as a teacher he should be exempt from being stabbed to prove they were carrying a corpse. ${ }^{17}$ On discarding his disguise, he approached some Roman soldiers and asked:

12 For the Republic, see (Lü 2018, p. 98). Cf. Polybius 3.59; 4.40. See also (McGing 2010, p. 144).

13 See (Schalit 1975, pp. 15-305; Hasan-Rokem 2000, pp. 171-89; Lerner 2010, p. 182; Kister 1998).

14 For a survey of the approaches that deny any historical verisimilitude to the Johanan ben Zakkai account, see (Ben-Shahar 2017, pp. 625-26).

15 "R. Joseph, or some say R. Akiba, applied to him the verse, '[God] turneth wise men backward and maketh their knowledge foolish' [Isa 44:25]. He [Rabban Johanan] ought to have said to him [Vespasian]: Let them [the Jews] off this time. He, however, thought that so much he would not grant, and so even a little would not be saved" (b. Git. 56b). See (Tropper 2005, p. 137; Marx 2010, p. 81).

16 According to Ben-Shahar (2017, pp. 655-656), the late Abot d. R. Nathan (B) contains an earlier tradition of the story.

17 This contrasts with the later versions, which present him as an opponent of the rebellion from the outset: see (Hasan-Rokem 2000, p. 190; Yisraeli-Taran 1997, pp. 52-53; Merchavia 1981, pp. 267, 276). 
"Where is the king?" They went and told Vespasian, "A Jew is asking for you." He said to them, "Let him come." On his arrival, Johanan exclaimed, "Vive domine Imperator!" Vespasian remarked, "You give me a royal greeting but I am not king; and should the king hear of it he will put me to death." He said to him: "If you are not the king you will be eventually, because the Temple will only be destroyed by a king's hand, as it is said, 'And Lebanon will fall by a mighty one' (Isa 10:34)." (Lam. Rab. $1.5 \$ 31$ (Soncino; cf. Cohen 1983, p. 102)

Like Josephus, who claimed to "know what was the law of the Jews," Rabban Johanan's prediction was based on his biblical erudition rather than foreign knowledge (Rajak 1983, p. 18; Marx 2010, pp. 63-65, 72). In contrast to Josephus, who appears to reflect a belief in "prophetic abilities" attained via study of the latter, Rabban ben Zakkai seems to have drawn upon an aggadic midrash (Ben-Shahar 2017, p. 637). ${ }^{18}$

By its very nature, this proficiency aided in understanding God's will also in relation to future events. Following the fulfillment of the prophecy, Vespasian asked Rabban Johanan how he would like to be rewarded. Jerusalem already having fallen, his primary concern was to rescue the Sages from death (Hasan-Rokem 2000, p. 197; Marx 2010, pp. 63-65, 72). He thus requested a place in which Judaism could survive without the Temple (Marx 2013, p. 74). The entreaty for "Yavneh and the Sages" appears to be a gloss, only appearing in the later versions, Josephus asserting that the survivors fled to Gofna in the Galilee rather than Yavneh on the eve of the destruction (B.J. 6.115-116) (Schalit 1975, pp. 317-21; Kister 1998, p. 518). Despite the (tendentious) editing of the rabbinic sources, the Romans settled Jews who surrendered in both Yavneh and Lod from 68 onward, the two cities subsequently becoming centers of Torah study (B.J. 4.130, 444; Yitzhak 2006, p. 158). ${ }^{19}$ The concentration of refugees in restricted locations reflected an imperial policy designed to ease military passage and the need to carefully monitor the population, in this case distancing Jews from the rebel headquarters in Jerusalem (Rosenfeld 1999, p. 9; 1993a, p. 150). Although the textual variations in the versions of the story may derive from the editors' unease with the report, Rabban Johanan appears to have been criticized in his own lifetime for not having fought hard enough to save Jerusalem (Yitzhak 2006, p. 154). ${ }^{20}$

Rabban Johanan's statements may have been uttered during interrogation by lower-ranked Roman soldiers rather than directly to Vespasian (Merchavia 1981, p. 272; Price 1992, p. 200). Jewish sources portray the latter as more moderate than his son Titus, whom they refer to as "the wicked," holding him directly responsible for the destruction of the Temple (cf. Abot R. Nat. B 6; Brezis 2015, p. 428). They thus diverge from Josephus who, while depicting the Roman commander as a wise, cautious, experienced ruler who saved Rome from disaster (albeit in not particularly warm terms), speaks of Titus with great affection. This circumstance appears to reflect the fact that the Wars were written at the end of Vespasian's life, only receiving official backing during Titus' days (Stern 1991, p. 406). Josephus' description, in turn, is inconsistent with the unfavorable one given by Suetonius (Tit. 7) (Price 2009, pp. 50, 66).

On several occasions in the Wars Josephus remarks that the Romans interrogated prisoners to decide who merited severe treatment. Thus, for example, he notes that

Despite his original edict that no one should desert alone (he wanted them to bring out their families too), Titus did in fact accept such individual refugees; but he appointed assessors to weed out any who deserved punishment.

(B.J. 6.385; cf. 6.225, 6.356)

18 In the wake of the destruction of the Temple, diverse interpretive traditions appear to have arisen with respect to the success of the revolt and the fate of the Temple: see (Ben-Shahar 2017, p. 662). The period also witnessed a plethora of prophets and homilists: see (Urbach 1987, p. 559).

19 For the subjugation of Yavneh and Ashdod and the prisoners taken by Vespasian, see (Alon 1977, p. 225; Rosenfeld 2010, pp. 41-42, 58).

20 For Rabban Johanan as a moderate leader, see (Urbach 1987, p. 596; Baer 1971, p. 185; Tropper 2005, p. 137). 
This method was already practiced during the biblical period, Sennacherib declaring in 701 BC after suppressing the revolt at Ekron: "The citizens who committed sinful acts I counted as a spoil, and I ordered the release of the rest of them, who had not sinned." ${ }^{21}$ In the wake of the destruction of the First Temple in 586 BCE, Nebuchadnezzar king of Babylon, gave similar instructions concerning Jeremiah:

Now Nebuchadnezzar king of Babylon gave charge concerning Jeremiah to Nebuzaradan the captain of the guard, saying, "Take him and look after him, and do him no harm; but do to him just as he says to you." So Nebuzaradan the captain of the guard sent Nebushasban, Rabsaris, Nergal-Sharezer, Rabmag, and all the king of Babylon's chief officers; then they sent someone to take Jeremiah from the court of the prison, and committed him to Gedaliah the son of Ahikam, the son of Shaphan, that he should take him home. So he dwelt among the people. (Jer 39:11-14; cf. 40:2-4) 22

Like the Assyrian Sennacherib, following the destruction of the First Temple (586 BC), the Babylonian Nebuchadnezzar takes no action against Jeremiah for his vehement opposition to the revolt against Babylonia—or indeed any other figures who held a similar position.

Roman sources also indicate that portents of Vespasian's success were evident before he set out. Suetonius, for example, reports the growth of a tree that presaged the fate of Vespasian and his siblings:

The first branch was delicate and soon withered, just as the girl who was born did not see out the year. The second was very strong and abundant, portending great good fortune, but the third was like a tree itself. It was because of this, they say, that the father, Sabinus, receiving further confirmation from a haruspex, announced to his mother that a grandson had been born to her who would be a Caesar. (Vesp. 5)

The commander received a further sign upon reaching Judaea. Consulting the "oracle of the divinity at Carmel," he received an answer "so encouraging as to assure him of success in anything he projected, however great or important it might be" (ibid). ${ }^{23}$ As we shall see, Vespasian sought out and made use of signs. This being a tradition, however, it was first and foremost a matter of concern for how he appeared to others (Levick 1999, pp. 69-70).

Tacitus and Dio Cassius also both reporting signs presaging Vespasian's future greatness, Josephus and Rabban Johanan may have been aware of such traditions, the former and the Sages in general both referring post-70 to the signs portending the imminent catastrophe about to befall them. ${ }^{24}$

\section{Third Case Study: Qorchi's Prophecy to Temüjin/Genghis Khan}

Let us now turn to the 12th- and 13th-century Mongol prophecies. The Secret History of the Mongols, which describes the life of Genghis Khan (b. 1162, d. 1227), appears to have been composed in the royal court some years following Genghis Khan's death, serving as a central source for the whole period. Consisting of a number of written and oral traditions, it also contains some legends. Rather than being an unadulterated paean to the ruler, it also adduces his weaknesses and limitations (Morgan 1993, pp. 9-13; Lane 2004, p. 15; Gabriel 2004, p. 5; Jackson 2005, p. 35; Man 2011, p. 132; Weatherford 2016, pp. 10-11).

21 Sennacherib's siege of Jerusalem (2.119B): see (Hallo 2002, vol. 2, p. 303).

22 For the divergent versions, see (Hoffman 2001, pp. 1, 709-10, 712-15; Goldstein 2013, pp. 37-46).

23 The Babylonian Talmud relates a similar act of Nero, who shot four arrows, all of which fell in Jerusalem (b. Git. 56a)—recalling Ezekiel's words to Nebuchadnezzar in Ezek 21:26.

24 Tacitus, Hist. 1.10, 2.78, 5.13; Cass. Dio 65.1; B.J. 6.5.3-4; b. Yoma 39b; y. Yoma 6, 43c; Abot R. Nat. B 7; (Overman 2002, p. 213; Schwartz 2014, p. 82; Beer 2011, pp. 210-11). Some scholars suggest that the story of Rabban Johanan's flight rests on the account of Jeremiah's escape through the city gate (Jer 38:12-16): see (Goldstein 2013, pp. 19, 40; Neusner 1962, p. 116). Fleeing in a time of distress is a well-known motif in both biblical and classical literature, however: see (Eph'al 1996, pp. 144-45). 
The founder of the Mongol empire was given the name Temüjin "Blacksmith" at birth after the Tartar leader who was captured/killed by his father on the eve of his birth. This in and of itself was regarded as a good omen for the newborn. ${ }^{25}$ It was complemented by the fact that, "At the time of his birth he was born clutching in his right hand a clot of blood the size of a knucklebone" - a tradition also reported by Rashid al-Din/Reşideddin Fazullah (1247-1318), an apostate Jewish historian and doctor who held a top-ranking post in the Mongol administration in Iran, in his Moğul Tarihi (SHM, 13 §59; MT 152 §232; Biran 2007, p. 89; Lane 2004, p. 121). However, the tradition does not appear in the history compiled by Alā' al-Dīn 'Ațā Malek Juwaynī (b. ca. 1226), the ruler of Iraq (GKH; Morgan 1993, p. 18). Significantly, over the years, the story of the sign given at his birth continued to develop, until we find it in a 19th-century Mongol source that recounts that he was born clasping a red diamond-a rainbow and other portents also manifesting themselves on the day of his birth (Goncugjab 2007, p. 36).

When he was nine, his father was poisoned by the Tartars as part of the ongoing warfare between the tribes in the region, the family being exiled to the steppes (MT, 144 §219, 152 §232; Biran 2007, pp. 33-34). Feeling betrayed, the youth-as wise and socio-politically adept as he was powerful and charismatic - sought to unite the Mongol tribes, who numbered between 700,000 and a million and had up until that point engaged in ceaseless intertribal warfare (Biran 2007, pp. 72, 75; Man 2009, pp. 34-36; 2011, pp. 99, 105; May 2012, p. 32; Weatherford 2010, pp. 39-44). ${ }^{26}$ His natural talents enabled him to turn them into an organized entity ruled by an established imperial establishment that became a vast empire (Morgan 1993, p. 59; Weatherford 2004, p. 67; Saunders 1971, p. 66). ${ }^{27}$

Coming to be regarded as a leader ca. 1185, some four years later Temüjin was already known as Genghis Khan - "the powerful lord." Taking control of the Mongol tribes in 1206, he attributed great importance to integrity and loyalty, especially with respect to mutual pacts (anda), believing faithfulness to be stronger than kinship—an innovative principle in Mongol culture (May 2012, p. 32; Biran 2007, p. 39; Weatherford 2004, pp. 26, 28-29, 50, 67; 2016, p. 117; Ratchnevski 1994, p. 7; Man 2011, pp. 110, 131; Morgan 1993, p. 37). He thus encouraged the repaying of one's friends and enemies alike (Ratchnevski 1994, pp. 63-64, 152; Lane 2004, p. 30).

In his youth, Temüjin made friends with an older lad by the name of Jamuqa, the two subsequently signing an anda (SHM, 35-38, §§105-107). Although they served together under the greater leader Ong Khan, they subsequently grew apart; the reasons for their estrangement remain obscure (MT, 174-175, 179 (§§264, 266, 272); GKH, 36-37, §27; SHM, 80-91, §§159-170; Gumilev 1987, pp. 145-46, 237). They thus found themselves on opposite sides of the battlefield, the Secret History recounting that, with greater forces, Jamuqa prevailed (SHM, 54, §129). According to Rashid al-Din Fazullah's Moğul Tarihi, however, Temüjin emerged victorious $(M T, 182$, §277). Today, the former version, which presents Genghis Khan in a more realistic fashion, is generally preferred (Gumilev 1987, p. 155; Weatherford 2016, p. 68). Despite the defeat, some of Jamuqa's men defected to Temüjin's camp, realizing that the latter was destined for greater power (Gumilev 1987, pp. 153-54). Amongst these was a top-ranking officer by the name of Qorchi, who came bearing a prophetic message for his new commander:

“Together Heaven and Earth have agreed: Temüjin shall be lord of the people!" and "I am drawing near carrying the people and bringing it to him." These heavenly signs appeared before my eyes; they revealed the future to me. Temüjin, if you become lord of the people, how will you please me for this augury?' Temüjin said, 'If it is indeed given to me to rule over the people as you say, I will make you a leader of ten thousand.' Qorči said, 'What kind of happiness is it for me, the man who foretold so many great affairs, merely to become the leader of ten thousand? Make me a leader of ten thousand, but in addition allow me to take

25 See (Fazlullah 1998, p. 139, §210, 152 §232 (MT); Alā’ al-Dīn 'Atā Malek Juvainī 1997, p. 35, §26 (GKH); de Rachewiltz 2006, vol. 1, pp. 13, 319-20, §59 (SHM); Onon 2011, 56 n. 146).

26 The cynical name "Mongol" was only attributed to a group of Tartar tribes in the eleventh century: see (GKH, $12 \S 15$; Ratchnevski 1994, pp. 7-8, 12; Weatherford 2004, p. xvi).

27 For Genghis Khan's desire to demonstrate his "divine right" to rule, see (Man 2014, p. 21). 
freely beautiful and fine girls from among the people, and let me have thirty as wives. And again, whatever I say, heed me closely!' (SHM, 1:48 §121) ${ }^{28}$

Although the Mongols believed that the gods could deliver messages via human agents-to whom they gave the ability to receive them-Genghis Khan himself appears not to have been convinced by prophets in general, seeking rather to control them (Weatherford 2016, p. 8; Onon 2011, p. 4; Ratchnevski 1994, p. 158). Herein, he differs from Vespasian. The sources occasionally recording tidings that came to him in intuitive dreams, over time he nonetheless appears to have come to regard himself as divinely chosen (Ratchnevski 1994, p. 160; Man 2011, p. 105).

According to Juwaynī, following his victory over Ong Khan, he was met by a prophet by the name of Teb-Tengri, who told him in god's name that his name would be changed to Genghis Khan and that he would become ruler of the earth $(G K H, 39)$. The 13th-century Armenian historian Grigor of Akner also notes that he received a divine dream (Grigor of Akanc 2003, pp. 293-94). ${ }^{29}$ Another historian of the same period, Kirakos Gandsakets'i's, describes a miraculous conception with a message for the people (Gandzakets'i's 1986, p. 234). ${ }^{30}$ The chronicle Flower of Histories of the East, written by the Armenian statesman and military officer Het'um and first published in 1307, similarly reports that an old man received a revelatory dream he delivered to Genghis Khan (Het'um the Historian 2004, Book 3, chapter 16). ${ }^{31}$ The Travels of Marco Polo, in contrast, attributes the Mongol ruler's rise to his natural abilities-integrity, wisdom, courage, and leadership qualities (Cordier 2014, chp. 47). John of Plano Carpini, whose History of the Mongols contains numerous legends, similarly adduces no omens or portents (John of Plano Carpini 1966, p. 19).

As time passed and it became clear that the prophecies had been fulfilled, Genghis Khan determined to reward Qorchi:

At that time you, Qorči, said, "If the prophecy comes true and if it is fulfilled by Heaven according to your wishes, let me have thirty women." Now, because it has come true, I shall favour you. Look at the fine women and fine girls of the people who have submitted to us and choose thirty women from among them.' So he ordered. (SHM, 1:139 §207)

In the continuation, the text relates how Qorchi, appointed general, was directed to take 30 of the beautiful women of the Qori Tumades tribe. Despite having surrendered to Genghis Khan, the tribal head refused to hand them over, taking Qorchi captive, together with the envoy sent to inquire of his whereabouts. In response, Genghis Khan attacked the tribe, giving Qorchi the women that he had promised him after the battle (SHM, $166 \$ 241)$.

\section{Conclusions}

All three prophecies foretell the rise of a commander to power by a defector or prisoner. Josephus surrendered to the Romans after the siege of Yodfat, Rabban Johanan gave himself up during the Roman siege of Jerusalem, and Qorchi joined forces with the young Genghis Khan at the beginning of his career after his defeat by Jamuqa. In the case of Vespasian and Genghis Khan, earlier omens and portents prior to the prophecies we have examined are recorded that also presaged their future greatness. When the prophecies were fulfilled, those who delivered them were rewarded by the commander-turned-emperor, Josephus being allowed to live and given a position in Rome, Rabban Johanan rescuing a remnant to ensure the continued existence of Judaism, and Qorchi being appointed general and given 30 beautiful women. The passages also appear to serve to extol military commanders not naturally due to inherit their eventual status, thereby granting them divine legitimacy. In all three

28 Qorchi appears to have wished for a wife every day of the month: see (de Rachewiltz 2006, p. 48).

29 https://archive.org/details/GrigorAknertsisHistoryOfTheNationOfArchersmongols.

30 https://archive.org/details/KirakosGanjaketsisHistoryOfTheArmenians.

31 https://archive.org/details/HetumTheHistoriansFlowerOfHistoriesOfTheEast. 
stories, the rulers are thus presented as men who kept their promise, rewarding those who "backed the right horse."

The two commanders-Vespasian and Temüjin/Genghis Khan-both appear to have sought legitimization at the time the prophecies were delivered, neither having legally inherited the throne, and those making the prophecies wanting to use the occasion for their personal/group benefit.

The comparison clearly reveals that the cultures under discussion-Rome, Judea, and Mongoliaregarded signs and prophecies as omens that were ignored at one's peril. The fact that dismissing led to disaster is evidenced by the account of Julius Caesar's assassination-a final action in defense of the Republic that hoped to prevent its replacement by an autocratic Caesar (Shotter 1991, pp. 16-17; Yavetz 1994, p. 183; cf. Shatzman 2001, pp. 256, 274; Baker 2007, pp. 152-53). In order to effect the changeover, Caesar not only required forces but also legitimization as part of the building of his image amongst the aristocracy and public (Southern 2014, p. 161; Yavetz 1988, pp. 38-57; 1992, pp. 166-72, 199-207). As we have seen above, the sources cite divine signs as proof of a rise to greatness. From Caesar's days onwards, indeed, an aura of sanctity and divine signs were attributed to the Roman ruler (Amit 2003, p. 63). The sources also attest that Julius Caesar's murder was preceded by omens. Being persuaded to ignore them, however, he departed for the Senate meeting at which he was killed (Suetonius, Jul. 81-82; Plutarch, Caes. 63-64; Kamm 2006, pp. 147-51; Santangelo 2013, pp. 236-40; cf. Suet. Galba 18-19; Vit. 18). Josephus similarly asserts that the zealots paid no attention to the signs heralding the failure of the rebellion against Rome, interpreting them as per their will in tendentious fashion and thus bringing destruction and exile upon the people (B.J. 2.22.1 [650], 6.5.3 [288-309]). Similarly, the Mongols were also accustomed to heeding signs. While Genghis Khan gave precedence to common sense, he neither disparaged nor ignored omens (SHM, 3 §13, 110-111 §189, 130-133 §201, 138 §206; Weatherford 2016, pp. 266-67; cf. Ratchnevski 1994, p. 160).

Comparison of these three cases from two historical periods reveals the nature of the phenomenon under discussion - the delivery of a prophecy of the rise to power of a military commander by a person who has recently joined his ranks, either involuntarily or voluntarily.

In all these examples, the seers (notable figures) turned to a commander who was seeking legitimacy-Rabban Johanan and Qorchi after they had voluntarily left their own camps, and Josephus being taken captive. The former two spoke succinctly, after which the commander's reaction is stated and a brief dialogue ensues. They explain how they reached the prophetic conclusion that the army chief's fortunes would turn. In contrast, Josephus' speech is more along the lines of a monologue, primarily designed to strengthen his trustworthiness. Although Vespasian was indeed initially suspicious of him, he was eventually persuaded by him, perhaps because other signs accompanied the prophecy. In all three instances, Josephus was in the greatest danger of losing his life, having played a significant role in the rebel forces fighting Rome. He thus turned to prophecy in order to stave off his execution. Rabban Johanan, on the other, abandoned the besieged city to the rebels, not necessarily facing any personal danger. His intention was altruistic - to save the Sages. Having deserted the victorious army, Qorchi prophesied to Temüjin on the basis of his understanding that the latter's failure was only temporary and that he would ultimately establish himself as ruler. Despite the divergences noted above, however, and the disparate historical and geographical circumstances between the three civilizations-Judah/Rome on the eve of the destruction of the Temple (69-70 CE) and Mongolia at the end of the 12th century - a number of striking affinities can be adduced. It is difficult to imagine that the Mongolian historian was familiar with the stories of Josephus' and Rabban Johanan's prophecies to Vespasian centuries earlier at a great geographical remove. Precisely this fact, however, despite the differences in the historical circumstances and the texts that record the events, reinforces their verisimilitude-i.e., the historical kernel of truth that lies at their heart. Both the new rulers of Rome and the new lord of Mongolia sought human and divine legitimacy for their regimes. Inter-regional and inter-period comparison thus provides us with deeper insight into how people from different cultures and times behave in similar situations, especially types of leadership. As Tacitus observes, "human nature is especially eager to believe the mysteries" (Hist. 1.22). 
Finally, a note regarding the comparative methodology is in order. I suggest that the use of this model enables demonstration of universal patterns of behavior in similar situations across historical and geographical divides. The fact that the sources from which the stories discussed above are drawn are historiographically complex raises questions regarding the verisimilitude of the tales. In his Jewish War-composed as a history in the best tradition of his time-inter alia Josephus sought to present his going over to the Romans in such a way as to avoid the impression that he was a traitor. He thus adopted an apologetic tone in order to show himself in the most favorable light. The account of Rabban Johanan b. Zakkai, in contrast, appears in a very different literary genre-namely rabbinic literature. While essentially legal material, this also contains aggada and important historical information. This story also occurs in several versions, evincing the editing to which it has been subject over time. The narrative of Qorchi is preserved in the Secret History of the Mongols, an epic-historical source that is nonetheless not an encomium.

As we saw above, it is often difficult to distinguish between historical facts and legends woven around heroic figures. The verisimilitude of all three of these cases must thus be substantiated. In this respect, the present interperiod and intergeographical comparison confirms a code of personal behavior. The documents analyzed also indicate that Josephus and Qorchi gained a measure of intimacy with the commander on the basis of their wisdom. This fact further recalls the example of Ibn Khaldūn from the period of the Mongolian Empire.

While Rabban Johanan sought religious autonomy under Roman sponsorship, in contrast, having no interest in courting Roman favor, he, too, behaved in similar fashion after turning himself over to the Roman army. The adducing of sources from later historical periods thus evinces that this episode is not drawn from Josephus-despite the fact that, after the event, the tale may well have been influenced by the traditions that developed in the wake of Josephus' deed (the Sages' unfamiliarity with the Jewish War notwithstanding). The two cases from the ancient world further support the historical verisimilitude of the account of Qorchi's deeds, performed in similar circumstances and recorded in the Secret History of the Mongols.

As we observed at the outset, the affinities between Mongol, biblical, and ancient history have now become the subject of scholarly research. While the findings remain quite general, I have sought herein to present and analyze sources that will substantiate this claim in more specific detail. I thus hope that this contribution may form the basis for further comparative research.

Funding: This research received no external funding.

Conflicts of Interest: The author declares no conflict of interest.

\section{References}

Adrados, Francisco Rodrigez. 1999. History of the Graeco-Roman Fable. 2 vols. Leiden: Brill.

Alon, Gedalyahu. 1977. Jews, Judaism and the Classical World: Studies in Jewish History in the Times of the Second Temple and Talmud. Translated by Israel Abrahams. Jerusalem: Magnes.

Amit, Moshe. 2003. A History of the Roman Empire. Jerusalem: Magnes. (In Hebrew)

Anbar, Moshe. 2007. Prophecy, Treaty-Making and Tribes in the Mari Documents. Jerusalem: Bialik Institute. (In Hebrew)

Asheri, David. 2004. A Possession for all Times: Greek Historians and History Writing in Greece and Rome. Jerusalem: Magnes. (In Hebrew)

Baden, Joel. 2013. The Historical David: The Real Life of an Invented Hero. New York: Harper-Collins.

Baer, Yitzhak. 1971. Jerusalem in the Times of the Great Revolt. Zion 36: 169-84. (In Hebrew).

Baker, Simon. 2007. Ancient Rome: The Rise and Fall of an Empire. London: BBC.

Bar-Efrat, Shimon. 1996. I Samuel: Introduction and Commentary. Mikra Leyisrael. Jerusalem: Magnes, Tel Aviv: Am Oved. (In Hebrew)

Barsted, Hans M. 2006. Sicdict Dominus: Mari Prophetic Texts and the Hebrew Bible. In Essays in Ancient Israel in its New Eastern Context: A Tribute to Nadav Na'aman. Edited by Yaira Amit, Ehud Ben zvi, Israel Finkelstein and Oded Lipschits. Winona Lake: Eisenbrauns, pp. 21-52. 
Bartlett, W. B. 2009. The Mongols: From Genghis Khan to Tamerlane. Gloucestershire: Amberley.

Baumgarten, Albert. 2007. What is Religious Extremism? In Religious Radicalism. Edited by Meir Litvak and Ora Limor. Jerusalem: Zalman Shazar Centre, pp. 43-56. (In Hebrew)

Beer, Moshe. 2011. The Sages of the Mishnah and the Talmud: Teachings, Activities and Leadership. Ramat-Gan: Bar-Ilan University Press. (In Hebrew)

Ben-Shahar, Meir. 2017. The Prediction to Vespasian. In Josephus and the Rabbis. Edited by T. Ilan and Vered Noam. Jerusalem: Yad Ben-Zvi, pp. 604-64. (In Hebrew)

Bilde, Per. 1988. Flavius Josephus between Jerusalem and Rome: His Life, His Works and Their Importance. Sheffield: Sheffield Academic Press.

Biran, Michal. 2007. Chinggis Khan. Oxford: Oxford University Press.

Bloch, Marc. 1953. The Historian's Craft: Reflections on the Nature and Uses of History and the Techniques and Methods of Those Who Write It. Translated by Peter Putnam. Toronto: Alfred Knopf.

Bloch, Marc. 1961. Feudal Society. Translated by L. A. Manyon. 2 vols. Chicago: Chicago University Press.

Breier, Idan. 2011. Time: Present and Past or Can We Interpret the Past through Contemporary Models? Devarim 4: 76-87. (In Hebrew).

Brezis, David. 2015. Between Zealotry and Grace: Anti-Zealot Trends in Rabbinic Thought. Ramat-Gan: Bar-Ilan University Press. (In Hebrew)

Brighton, Mark A. 2009. The Sicarii in Josephus's Judean War: Rhetorical Analysis and Historical Observations. Atlanta: SBL.

Carr, Edward Hallett. 1964. What Is History? 2nd ed. London: Penguin.

Charvát, Petr. 2013. The Birth of the State: Ancient Egypt, Mesopotamia, India and China. Prague: Karolinum Press.

Cohen, Abraham. 1983. Midrash Rabbah: Lamentations. London: Soncino.

Cordier, Henri, ed. 2014. The Travels of Marco Polo: The Complete Yule-Cordier Edition. Available online: https://ebooks.adelaide.edu.au/p/polo/marco/travels/complete.html\#book1.47 (accessed on 30 March 2019).

Cotton, Hanna M., and Werner Eck. 2005. Josephus' Roman Audience: Josephus and the Roman Elites. In Flavius Josephus and Flavian Rome. Edited by Jonathan Edmondson, Steve Mason and James Rives. Oxford: Oxford University Press, pp. 37-52.

Cox, Michael, Tim Dunne, and Ken Booth. 2001. Introduction: Empires, Systems and States: Great Transformations in International Politics. In Empires, Systems and States: Great Transformations in International Politics. Edited by Michael Cox, Tim Dunne and Ken Booth. Cambridge: Cambridge University Press, pp. 1-16.

Curran, John. 2011. Flavius Josephus in Rome. In Flavius Josephus: Interpretation and History. Edited by Jack Pastor, Pnina Stern and Menahem Mor. Leiden: Brill, pp. 65-86.

de Rachewiltz, Igor. 2006. The Secret History of the Mongols: A Mongolian Epic Chronicle of the Thirteenth Century. Leiden: Brill.

den Hollander, William. 2011. Josephus, the Emperors, and the City of Rome. Leiden: Brill.

Desjarlais, Robert, and C. Jason Throop. 2011. Phenomenological Approaches in Anthropology. Annual Review of Anthropology 40: 87-102. [CrossRef]

Dunn, James D. G. 1981. Jesus the Prophet. The Furrow 32: 487-95.

Durkheim, E. 1982. The Rules of Sociological Method. Translated by W. D. Halls. New York: Free Press.

Eilat, Moshe. 1998. Samuel and the Foundation of Kingship. Jerusalem: Magnes. (In Hebrew)

Engels, David. 2007. Das Römische Vorzeichenwesen (753-27 v. Chr.): Quelen, Terminologie, Kommentar, historische Entwicklung. Stuttgart: Franz Steiner.

Eph'al, Israel. 1996. Siege and Its Ancient Near Eastern Manifestations. Jerusalem: Magnes. (In Hebrew)

Eph'al-Jaruzelska, Izabela. 2009. Prophets, Royal Legitimacy and War in Ancient Israel. Warsaw: Warsaw University Press.

Fazlullah, Rashiduddin. 1998. Moğul Tarihi I. Kisim. Translated by Wheeler M. Thackston. Cambridge: Harvard University Press.

Feldman, Louis H. 1998. Josephus's Interpretation of the Bible. Berkeley: University of California Press.

Feldman, Louis H. 2003. Prophets and Prophecy in Josephus. In Prophets, Prophecy, and Prophetic Texts in Second Temple Judaism. Edited by Michael H. Floyd and Robert D. Haak. New York: T\&T Clark, pp. 210-39.

Fenton, Terry. 2001. Israelite Prophecy: Characteristics of the First Protest Movements. In The Elusive Prophet: The Prophet as a Historical Person, Literary Character and Anonymous Artist. Edited by Johannes C. de Moor. Leiden: Brill, pp. 129-41. 
Fidler, Ruth. 2005. "Dreams Speak Falsely"?: Dream Theophanies in the Bible-Their Place in Ancient Israelite Faith and Traditions. Jerusalem: Magnes. (In Hebrew)

Fischel, Walter Joseph. 1952. Ibn Khaldūn and Tamerlane. Berkeley: University of California Press.

Frantz-Szabó, Gabriella. 1995. Hittite Witchcraft, Magic and Divination. In Civilizations of the Ancient Near East. Edited by Jack M. Sasson. 4 vols. New York: Charles Scribner's Sons, pp. 2007-19.

Fuks, Alexander. 2005. Thucydides the Historian. In Greek Historians and Greek Historiography. Edited by David Asheri. Jerusalem: Bialik Institute, pp. 111-43. (In Hebrew)

Gabriel, Richard A. 2004. Genghis Khan's Greatest General: Subotai the Valiant. Norman: University of Oklahoma Press.

Gandzakets'i's, Kirakos. 1986. History of the Armenians. Translated by Robert Bedrosian. Available online: https://archive.org/details/KirakosGanjaketsisHistoryOfTheArmenians (accessed on 30 May 2019).

Garsiel, Moshe. 2018. The Book of Samuel: Studies in History, Historiography, and Poetics Combined. Jerusalem: Rubin Mass.

Gelander, Shamai. 2008. Two Peoples into One: Belief, Religion and Cultural Environment in Israel and Judah in Biblical Narratives and Historiography. Jerusalem: Magnes. (In Hebrew)

Goldstein, Ronnie. 2013. The Life of Jeremiah: Tradition about the Prophet and Their Evolution in Biblical Times. Jerusalem: Magnes. (In Hebrew)

Goldsworthy, Adrian. 1992. Pax Romana: War, Peace, and Conquest in the Roman World. New Haven: Yale University Press.

Goncugjab. 2007. The Pearl Rosary: Mongol Historiography in Early Nineteenth Century Ordos. Translated by Johan Elverskog. Bloomington: Indiana University Press.

Goodman, Martin. 1987. The Ruling Class of Judaea: The Origins of the Jewish Revolt against Rome A.D. 66-70. Cambridge: Cambridge University Press.

Goodman, Martin. 2001. The Roman World: 44BC-AD180. London and New York: Routledge.

Goodman, Martin. 2007. Rome and Jerusalem: The Clash of Ancient Civilizations. New York: Bloomsbury T\&T Clark. Goodman, Martin. 2017. Josephus: The Jewish War. Translated by M. Hammond. Oxford: Oxford University Press.

Grabbe, Lester L. 2003. 'Thus Spake the Prophet Josephus ... ': The Jewish Historian on Prophets and Prophecy. In Prophets, Prophecy, and Prophetic Texts in Second Temple Judaism. Edited by Michael H. Floyd and Robert D. Haak. New York: T\&T Clark, pp. 240-47.

Gray, Rebbeca. 1993. Prophetic Figures in Late Second Temple Jewish Palestine: The Evidence from Josephus. New York: Oxford University Press.

Grayson, Kirk A. 2002. Assyrian Rulers of the Early First Millennium BC II (858-754 BC). Toronto: Toronto University Press.

Grigor of Akanc. 2003. History of the Nation of Archers. Translated by Robert Bedrosian. Available online: https://archive.org/details/GrigorAknertsisHistoryOfTheNationOfArchersmongols (accessed on 30 March 2019).

Gumilev, Lev Nikolaevich. 1987. Searches for an Imaginary Kingdom: The Legend of the Kingdom of Prester John. Translated by Robert Ernest Frederick Smith. Cambridge: Cambridge University Press.

Hadas-Lebel, Mireille. 1993. Flavius Josephus: Eyewitness to Rome's First-Century Conquest of Judaea. Translated by Richard Miller. New York: Simon \& Schuster.

Hägg, Tomas. 2012. The Art of Biography in Antiquity. New York: Cambridge University Press.

Hajdu, P. Péter, and György C. Kálmán. 2019. Comparing Cultural Practices. Neohellicon 46: 387-92. [CrossRef]

Halbertal, Moshe, and Stephen Holms. 2017. The Beginning of Politics: Power in the Biblical Book of Samuel. Princeton: Princeton University Press.

Hallo, William W., ed. 2002. Context of Scripture. 3 vols. Leiden: Brill.

Hasan-Rokem, Galit. 2000. The Web of Life: Folklore in Rabbinic Literature. Stanford: Stanford University Press.

Hengel, Martin. 1989. The Zealots: Investigations into the Jewish Freedom Movement in the Period from Herod I until 70 A.D. Translated by David Smith. Edinburgh: T\&T Clark.

Hertzberg, Hans Wilhelm. 1964. IEII Samuel: A Commentary. Translated by J. S. Bowden. London: SCM.

Het'um the Historian. 2004. History of the Tartars [The Flower of Histories of the East]. Translated by Robert Bedrosian. Available online: https://archive.org/details/HetumTheHistoriansFlowerOfHistoriesOfT heEast (accessed on 30 March 2019).

Hoffman, Yair. 2001. Jeremiah: Introduction and Commentary. Jerusalem: Magnes. (In Hebrew) 
Howell-Chapman, Honora. 2005. Spectacle in Josephus' Jewish War. In Flavius Josephus and Flavian Rome. Edited by Jonathan Edmondson, Steve Mason and James Rives. Oxford: Oxford University Press, pp. 289-313.

Hsü, Immanuel C. Y. 2000. The Rise of Modern China, 6th ed. New York and Oxford: Oxford University Press.

Jackson, Peter. 2005. The Mongols and the West, 1221-410. London and New York: Routledge.

Jassen, Alex P. 2008. Prophets and Prophecy in the Qumran Community. Association for Jewish Studies Review 32: 299-334. [CrossRef]

John of Plano Carpini. 1966. History of the Mongols. In Mission to Asia: Narratives and Letters of the Franciscan Missionaries in Mongolia and China in the Thirteenth and Fourteenth Centuries. Edited by Christopher Dawson. Available online: https://archive.org/details/Dawson1966MissionToAsia (accessed on 30 March 2019).

Jonquière, Tessel M. 2011. Josephus at Jotapata: The Way Josephus Wrote What He Wrote. In Flavius Josephus: Interpretation and History. Edited by Jack Pastor, Pnina Stern and Menahem Mor. Leiden: Brill, pp. 217-26.

Juvainī, 'Ala-ad-Din 'Ata-Malik. 1997. Genghis Khan: The History of the World Conqueror. Translated by John Andrew Boyle. Manchester: UNESCO Publishing.

Kamm, Antony. 2006. Julius Caesar: A Life. London and New York: Routledge.

Karhonen, Tua. 2019. Anthropomorphism and the Aesopic Animal Fables. In Animals and their Relations to Gods, Humans and Things in Ancient World. Edited by Raija Mattila, Sanae Ito and Sebastian Fink. Wiesbaden: Springer, pp. 211-31.

Kedar, Benjamin Z. 2009. Outlines for Comparative History Proposed by Practicing Historians. In Explorations in Comparative History. Edited by Benjamin Z. Kedar. Jerusalem: Magnes, pp. 5-19.

Kessler-Guinan, Ann. 2002. A Severed Head Laughed: Stories of Divinatory Interpretation. In Magic and Divination in the Ancient World. Edited by Leda Jean Ciraolo and Jonathan Seidel. Leiden: Brill, pp. 7-40.

Kister, Menahem. 1998. Legends of the Destruction of the Second Temple in Avot de-Rabbi Natan. Tarbiz 67: 483-529. (In Hebrew).

Klawans, Jonathan. 2012. Josephus and the Theologies of Ancient Judaism. New York: Oxford University Press.

Klein, Ralph W. 1983. Word Biblical Commentary Vol. 10, 1 Samuel. Nashville: Thomas Nelson.

Knibbe, Kim, and Peter Versteeg. 2008. Assessing Phenomenology in Anthropology: Lessons from the Study of Religion and Experience. Critique of Anthropology 28: 47-62. [CrossRef]

Kokaz, Nancy. 2001. Between Anarchy and Tyranny: Excellence and the Pursuit of Power and Peace in Ancient Greece. In Empires, Systems and States: Great Transformations in International Politics. Edited by Michael Cox, Tim Dunne and Ken Booth. Cambridge: Cambridge University Press, pp. 91-102.

Lane, George. 2004. Genghis Khan and Mongol Rule. Westport: Greenwood.

Lattimore, Richard. 1934. Portents and Prophecies in Connection with Emperor Vespasian. The Classical Journal 29: 441-49.

Lerner, Miron Bialik. 2010. A Hebrew Adaptation of the Escape of Rabban Yohanan ben Zakkai from Jerusalem under Siege. Sidra 24-25: 181-214. (In Hebrew).

Levick, Barbara. 1999. Vespasian. London and New York: Routledge.

Levin, Yigal. 2011. Rab-shakeh's Hebrew Speech: History versus Rhetoric. In New Studies on Jerusalem. Edited by Eyal Baruch, Ayelet Levy-Reifer and Avraham Faust. Ramat-Gan: Bar-Ilan University Press, vol. 17, pp. 137-49. (In Hebrew)

Levin, Yigal. 2015. How did Rabshakeh Know the Language of Judah? In Marbeh Hokmah: Studies in the Bible and in the Ancient Near East in Loving Memory of Victor Avigdor Hurowitz. Edited by Edward L. Greenstein, Mayer I. Gruber, Peter Machinist, Shalom M. Paul and Shamir Yonah. Winona Lake: Eisenbrauns, pp. 323-37.

Levison, John R. 2003. Philo's Personal Experience and the Persistence of Prophecy. In Prophets, Prophecy, and Prophetic Texts in Second Temple Judaism. Edited by Michael H. Floyd and Robert D. Haak. New York: Bloomsbury T\&T Clark, pp. 194-209.

Lorberbaum, Yair. 2008. Subordinated King: Kingship in Classical Jewish Literature. Ramat-Gan: Bar-Ilan University Press. (In Hebrew)

Lü, Houliang. 2015. World Citizens vs. People Chosen by God: Josephus between Judaism and the Roman Empire. Journal of Ancient Civilizations 30: 85-116.

Lü, Houliang. 2018. Dramatic Elements in Polybius' General History: An Analysis Based on the Model of Connectivity of the Ancient Mediterranean World. Journal of Ancient Civilizations 33: 83-112.

Mace, Ruth, and Mark Pagel. 1994. Comparative Method in Anthropology. Current Anthropology 35: 549-64. [CrossRef] 
Mader, Gottfried. 2000. Josephus and the Politics of Historiography: Apologetic and Impression Management in the Bellum Judaicum. Leiden: Brill.

Malamat, Abraham. 1995. Prophecy at Mari. In "The Place is Too Small for Us": The Israelite Prophets in Recent Scholarship. Edited by Robert. P. Gordon. Winona Lake: Eisenbrauns, pp. 50-73.

Man, John. 2009. The Leadership Secrets of Genghis Khan. London: Bantam.

Man, John. 2011. Genghis Khan: Life, Death and Resurrection. London: St. Martin's Griffin.

Man, John. 2014. The Mongol Empire: Genghis Khan, His Heirs and the Founding of Modern China. London: Transworld.

Mandelbaum, Maurice. 1980. Some Forms and Uses of Comparative History. American Studies International 18: 19-34.

Marx, Dalia. 2010. An Ancient Myth in the Service of the Present: Rabban ben Zakkai's Escape from Jerusalem and the Establishment of Yavneh. Aqedemot 24: 156-76. (In Hebrew).

Marx, Dalia. 2013. The Emergence of the People of the Book: Rabban Yohanan ben-Zakkai and the Establishment of Yavneh. Mo'ed 21: 56-85. (In Hebrew).

Mason, Steve. 2005a. Figured, Speech and Irony in T. Flavius Josephus. In Flavius Josephus and Flavian Rome. Edited by Jonathan Edmondson, Steve Mason and James Rives. Oxford: Oxford University Press, pp. 243-88.

Mason, Steve. 2005b. Of Audience and Meaning: Reading Josephus' Bellum Judaicum in the Context of a Flavian Audience. In Josephus and Jewish History in Flavian Rome and Beyond. Edited by Joseph Sievers and Gaia Lembi. Leiden: Brill, pp. 71-100.

May, Timothy. 2012. The Mongol Conquests in World History. London: Reaktion.

McCarter, P. Kyle, Jr. 1980. 1 Samuel: A New Translation with Introduction, Notes E Commentary. New York: Doubleday.

McGing, Brian. 2010. Polybius: Histories. Oxford: Oxford University Press.

McKanzie, Steven L. 2000. King David: A Biography. New York: Oxford University Press.

McLaren, James S. 2005. Josephus and Titus: The Vanquished Writing about the Victor. In Josephus and Jewish History in Flavian Rome and Beyond. Edited by Joseph Sievers and Gaia Lembi. Leiden: Brill, pp. 287-95.

Mellor, Ronald. 1999. The Roman Historians. London and New York: Routledge.

Merchavia, Hen-Melech. 1981. Rabban Johanan ben Zakkai: What He Was and Was Not. Ha'uma 64: $265-77$. (In Hebrew).

Miller, Maxwell J., and John H. Hayes. 2006. A History of Ancient Israel and Judah, 2nd ed. London: Westminster John Knox.

Morgan, David. 1993. The Mongols. Oxford: Oxford University Press.

Morris, Ellen F. 2010. Opportunism in Contested Lands, B.C. and A.D., or How Abdi-Asurta, Aziru, and Padsha Khan Zadran Got away with Murder. In Millions of Jubilees: Studies in Honor of David Silverman. Edited by Zahi Howass and Jennifer Hooser-Wagner. Cairo: Supreme Council of Antiquity Press, pp. 413-38.

Murnane, William J. 2003. Response to D.B. Redford. In Egyptology at the Dawn of the Twenty-First Century. Edited by Zahi Hawass. Cairo: American University in Cairo Press, pp. 15-19.

Neusner, Jacob. 1962. A Life of Rabban Yohanan Ben Zakkai ca. 1-80 C.E. Leiden: Brill.

Newell, Raymond R. 1989. The Forms and Historical Value of Josephus' Suicide Accounts. In Josephus, the Bible and History. Edited by Louis H. Feldman and Gohei Hata. Leiden: Brill, pp. 278-94.

Nikiprowetzky, Valentin. 1989. Josephus and the Revolutionary Parties. In Josephus, the Bible and History. Edited by Louis H. Feldman and Gohei Hata. Leiden: Brill, pp. 216-36.

Nissinen, Martti. 2003. Prophets and Prophecy in the Ancient Near East. Atlanta: Society of Biblical Literature.

Nissinen, Martti. 2017. Ancient Prophecy: Near Eastern, Biblical, and Greek Perspectives. Oxford: Oxford University Press.

Noam, Vered. 2012. Did the Rabbis Know Josephus' Works? Tarbiz 81: 367-95. (In Hebrew).

Onon, Urgunge. 2011. The Secret History of the Mongols: The Life and Times of Chinggis-Khan. London and New York: Routledge.

Overman, Andrew J. 2002. The First Revolt and Flavian Politics. In The First Jewish Revolt: Archaeology, History, and Ideology. Edited by Andrea M. Berlin and Andrew J. Overman. London and New York: Routledge, pp. 213-20. 
Parente, Fausto. 2005. The Importance of Titus, or Josephus' Bellum Judacium as an Example of 'Pathetic' Historiography'. In Josephus and Jewish History in Flavian Rome and Beyond. Edited by Joseph Sievers and Gaia Lembi. Leiden: Brill, pp. 45-70.

Perez, Louis G. 1998. The History of Japan. Westport: Greenwood.

Price, Jonathan J. 1992. Jerusalem under Siege: The Collapse of the Jewish State 66-70 C.E. Leiden: Brill.

Price, Jonathan J. 2009. Yosef Ben-Matityahu. In [Titus] Flavius Josephus, History of the Jewish War Against the Romans. Translated by Lisa Ullman. Jerusalem: Magnes. (In Hebrew)

Pucci, Miriam. 1982. On the Tendentiousness of Josephus' Historical Writing. In Josephus Flavius: Historian of Eretz-Israel in the Hellenistic-Roman Period. Edited by Uriel Rapport. Jerusalem: Magnes, pp. 117-31. (In Hebrew)

Puchala, Donald J. 2003. Theory and History in International Relations. New York and London: Routledge.

Rajak, Tessa. 1983. Josephus: The Historian and his Society. London: Fortress.

Rajak, Tessa. 2005. Josephus in the Diaspora. In Flavius Josephus and Flavian Rome. Edited by Jonathan Edmondson, Steve Mason and James Rives. Oxford: Oxford University Press, pp. 79-100.

Raphals, Lisa. 2013. Divination and Prediction in Early China and Ancient Greece. Cambridge: Cambridge University Press.

Rappaport, Uriel. 2006. John of Gischala: From the Mountains of Galilee to the Walls of Jerusalem. Available online: https://www.academia.edu/2383453/JOHN_OF_GISCHALA_From_the_mountains_of_Galilee_to _the_Walls_of_Jerusalem_2013._An_English_translation_of_the_Hebrew_edition_of_2006 (accessed on 30 March 2019).

Ratchnevski, Paul. 1994. Genghis Khan: His Life and Legacy. Translated by Thomas N. Haining. Oxford: Oxford University Press.

Regev, Eyal. 2011. Josephus, the Temple, and the Jewish War. In Flavius Josephus: Interpretation and History. Edited by Jack Pastor, Pnina Stern and Menahem Mor. Leiden: Brill, pp. 279-93.

Rosenberger, Veit. 1998. Gezähmte Götter: Das Predigienwesen der römischen Republik. Stuttgart: Franz Steiner.

Rosenfeld, Ben-Zion. 1993a. The Changing Significance of the Name 'Yavne' in Rabbinic Tradition. In Jews and Judaism in the Second Temple, Mishna and Talmud Period: Studies in Honor of Shmuel Safrai. Edited by Isaiah Gafni, Aharon Oppenheimer and Menahem Stern. Jerusalem: Magnes, pp. 149-64. (In Hebrew)

Rosenfeld, Ben-Zion. 1993b. Liminal Time from the Destruction of the Second Temple until the Establishment of the Centre in Yavne: 70-85/90 CE. In Jews and Christians in the First and Second Centuries: The Interbellum 70-132 CE. Edited by Joshua J. Schwartz and Peter J. Tomson. Leiden: Brill, pp. 142-57.

Rosenfeld, Ben-Zion. 1999. Lod and Its Sages in the Period of the Mishnah and the Talmud. Jerusalem: Yad Ben-Zvi. (In Hebrew)

Rosenfeld, Ben-Zion. 2010. Torah Centers and Rabbinic Activity in Palestine 70-400 C.E.: History and Geographic Distribution. Leiden: Brill.

Santangelo, Frederico. 2013. Divination, Prediction, and the End of the Roman Republic. Cambridge: Cambridge University Press.

Saunders, John Joseph. 1971. The History of the Mongol Conquests. London: Routledge.

Schalit, Abraham. 1975. Die Erhebung Vespasians nach Flavius Josephus, Talmud und Midrasch: Zur Geschichte einer messianischen Prophetie. In Aufstieg und Niedergang der römischen Welt II. Edited by Hildegard Temporini and Wolfgang Haase. Berlin: W. de Gruyter, pp. 208-327.

Schnegg, Michael. 2014. Anthropology and Comparison: Methodological Challenges and Tentative Solution. Zeitschrift für Ethnologie 139: 55-72.

Schremer, Adiel. 2005. Stammaitic Historiography. In Creation and Composition in the Contribution of the Bavli Redactors (Stammain) to the Aggada. Edited by Jeffrey L. Rubenstein. Tubingen: Mohr Siebeck, pp. 219-36.

Schwartz, Seth. 1990. Josephus and Judaean Politics. Leiden: Brill.

Schwartz, Daniel R. 2007. Flavius Josephus, Vita: Introduction, Hebrew Translation, and Commentary. Jerusalem: Magnes. (In Hebrew)

Schwartz, Daniel R. 2011. Josephus, Catulus, Divine Providence, and the Date of the Judaean War. In Flavius Josephus: Interpretation and History. Edited by Jack Pastor, Pnina Stern and Menahem Mor. Leiden: Brill, pp. 331-52.

Schwartz, Seth. 2014. The Ancient Jews from Alexander to Muhammad. Cambridge: Cambridge University Press.

Seward, Desmond. 2009. Jerusalem's Traitor: Josephus, Masada and the Fall of Judea. Cambridge: Da Capo. 
Shatzman, Israel. 2001. A History of the Roman Republic. Jerusalem: Magnes. (In Hebrew)

Shillony, Ben-Ami. 2001. The Culture and History of Premodern Japan. Tel Aviv: Schoken. (In Hebrew)

Shotter, David. 1991. Augustus Caesar. London and New York: Routledge.

Singer, Itamar. 2004. The Hittites in the Bible Revisited. Zmanim 87: 4-21. (In Hebrew).

Southern, Patricia. 1998. Augustus (Roman Imperial Biographies). London and New York: Routledge.

Southern, Patricia. 2014. Ancient Rome: Ancient Rome: The Rise and Fall of an Empire 753 BC-AD 476. London: Amberley.

Sowell, Thomas. 2002. A Conflict of Visions: Ideological Origins of Political Struggles. New York: Basic.

Spilsbury, Paul S. 2005. Reading the Bible in Rome: Josephus and the Constraints of Empire. In Josephus and Jewish History in Flavian Rome and Beyond. Edited by Joseph Sievers and Gaia Lembi. Leiden: Brill, pp. 209-27.

Stern, Menahem. 1991. Studies in Jewish History: The Second Temple Period. Edited by Moshe Amit, Isaiah Gafni and Moshe David Herr. Jerusalem: Magnes. (In Hebrew)

Temin, Peter. 2013. The Roman Market Economy. Princeton: Princeton University Press.

Thucydides. 2013. The War of the Peloponnesians and the Athenians. Translated by J. Mynott. Cambridge: Cambridge University Press.

Tiemeyer, Lena-Sofia. 2009. The Priests and the Temple Cult in the Book of Jeremiah. In Prophecy in the Book of Jeremiah. Edited by Hans M. Barstad and Reinhard G. Kratz. Berlin: de Gruyter, pp. 233-64.

Tod, Emmanuel. 2003. After the Empire: The Breakdown of American Order. New York: Columbia University Press. Tropper, Amram. 2005. Yohanan Ben Zakkai, Amicus Caesaris: A Jewish Hero in Rabbinic Eyes. Jewish Studies 4: $133-49$.

Uffenheimer, Benjamin. 1984. Early Prophecy in Israel, 2nd ed. Jerusalem: Magnes. (In Hebrew)

Urbach, Efraim Elimelech. 1987. The Sages: Their Concepts and Beliefs. Jerusalem: Magnes.

Valbelle, Dominique. 2003. Response to D.B. Redford. In Egyptology at the Dawn of the Twenty-First Century. Edited by Zahi Hawass. Cairo: American University in Cairo Press, pp. 20-22.

Van De Mieroop, Marc. 2016. Philosophy before the Greeks: The Pursuit of Truth in Ancient Babylonia. Princeton: Princeton University Press.

Weatherford, Jack. 2004. Genghis Khan and the Making of the Modern World. New York: Three Rivers Press.

Weatherford, Jack. 2010. The Secret History of the Mongol Queens: How the Daughters of Genghis Khan Rescued His Empire. New York: Crown.

Weatherford, Jack. 2016. Genghis Khan and the Quest for God: How the World's Greatest Conqueror Gave Us Religious Freedom. New York: Viking.

Weber, Gregor. 2000. Kaiser, Träume und Visionen in Prinzipat und Spätantike. Stuttgart: Franz Steiner.

Westall, Richard. 2016. The Sources of Cassius Dio for the Roman Civil Wars of 49-30 BC. In Cassius Dio: Greek Intellectual and Roman Politian. Edited by Jesper Majbom Madsen and Carsten Hjort Lange. Leiden: Brill, pp. 51-75.

Wright, Jacob L. 2014. David: King of Israel and Caleb in Biblical Memory. New York: Cambridge University Press.

Yavetz, Zvi. 1988. Plebs and Princeps. New Brunswick: Transaction.

Yavetz, Zvi. 1992. Julius Caesar: The Limits of Charisma. Tel Aviv: Dvir. (In Hebrew)

Yavetz, Zvi. 1994. Augustus: The Victory of Moderation. Tel Aviv: Dvir. (In Hebrew)

Yisraeli-Taran, Anat. 1997. The Legends of the Destruction. Tel Aviv: Hakibbutz Hameuchad. (In Hebrew)

Yitzhak, Ronen. 2006. 'Give Me Yavneh and the Sages': The Legend of Rabban Johanan ben Zakkai's Escape from Jerusalem. Shamatin 164: 149-59. (In Hebrew).

Zagorin, Perez. 2005. Thucydides: An Introduction for the Common Reader. Princeton: Princeton University Press.

Zhang, Y. 2001. System, Empire and State in Chinese International Relations. In Empires, Systems and States: Great Transformations in International Politics. Edited by Michael Cox, Tim Dunne and Ken Booth. Cambridge: Cambridge University Press, pp. 43-64.

(C) 2019 by the author. Licensee MDPI, Basel, Switzerland. This article is an open access article distributed under the terms and conditions of the Creative Commons Attribution (CC BY) license (http://creativecommons.org/licenses/by/4.0/). 